\title{
ANALISIS KURIKULUM JURUSAN PENDIDIKAN SENI TEATER ETHIOPIA
}

\author{
Girmaw Ashebir Sinshaw \\ Theatre Arts Department, Addis Ababa University, Ethiopia \\ E-mail: girmawashebir@gmail.com
}

\begin{abstract}
Abstrak
Tujuan penulisan artikel ini adalah untuk menganalisis pendidikan seni teater Ethiopia sebagai bentuk seni kreatif. Di Ethiopia, seni teater baru terbentuk tahun 1978, yang hingga sekarang belum menunjukkan kemajuannya. Kurikulum pendidikan seni teater di Ethiopia belum terlihat baik, dalam arti masih terdapat kekurangan di sana sini, sehingga sampai sekarang masih perlu penyempurnaan. Pendidikan seni teater ditopang oleh jurusan seni yang lain di Universitas Addis Ababa. Hal ini menyebabkan aspek musik, tari, seni rupa, dan seni kriya ikut membentuk terbentuknya pendidikan seni teater. Sekarang, pendidikan seni teater disuntik dengan seni teater tradisional yang menyebabkan bentuknya menjadi seni kreatif namun tidak menunjukkan teater yang mapan. Setiap teater di Ethiopia memilih bahan baku untuk memakmurkan pendidikan seni teater yang sekarang sedang digarap dalam kurikulum pendidikan seni teater Ethiopia.
\end{abstract}

Kata Kunci: teater, pendidikan seni, kurikulum, senikreatif, Ethiopia

\section{CURRICULUM ANALYSIS OF THETHEATRE ARTS EDUCATION DEPARTMENT IN ETHIOPIA}

\begin{abstract}
The purpose of this article is to analyze the theatrearts education in Ethiopia as a form of creative arts. In Ethiopia, the new theatrearts were formed in 1978, which until now has not shown significant progress. There are still shortages here and there in the curriculum for theatre arts education in Ethiopia, so that it still needs improvement. Theatre education is supported by other art majors at Addis Ababa University. This has caused aspects of music, dance, visual arts, and art to form the formation of theatrearts education. Now, the theatrearts education isinjected with traditional theatre arts, causing their form to become creative arts but not showing established theatre. Likewise, theatre arts in Ethiopia choose raw materials to prosper the theatrearts education which is now being worked on in the Ethiopian theatre arts education curriculum.
\end{abstract}

Keywords: theatre, arts education, curriculum, creative arts, Ethiopia

\section{PENDAHULUAN}

Seni pertunjukan berkisar dari musik vokal dan instrumental, tarian dan teater hingga pantomim, syair dan seterusnya. Mereka termasuk banyak ekspresi budaya yang mencerminkan kreativitas manusia dan yang juga ditemukan, sampai batas tertentu, di banyak domain warisan budaya takbenda lainnya. Teater adalah bentuk kolaboratif seni rupa yang menggunakan penampil langsung, biasanya aktor atau aktris untuk menyajikan pengalaman peristiwa nyata atau yang dibayangkan di hadapan penonton langsung di panggung. Para pemain dapat mengkomunikasikan pengalaman ini kepada hadirin melalui kombinasi gerakan, ucapan, lagu, musik dan tarian. Elemen-elemen seni, seperti pemandangan yang dilukis dan dekorasi 
panggungdan pencahayaan digunakan untuk meningkatkan penampilan fisik, kehadiran, dan kedekatan pengalaman.

Tempat khusus pertunjukan teater ini juga dinamai dengan kata "teater" yang berasal dari bahasa Yunani Kuno (théatron, "tempat untuk melihat"), " $\theta \varepsilon \alpha ́$ o $\mu \alpha \imath "$ (theáomai, "untuk melihat", "untuk menonton", "untuk mengamati"). Teater Barat modern, sebagian besar, berasal dari drama Yunani kuno yang darinya ia meminjam istilah teknis, klasifikasi menjadi genre, dan banyak tema, karakter, dan elemen plot.

Seniman teater Patrice membuka definisi teater, bahasa teater, penulisan panggung dan kekhasan teater sebagai ekspresi sinonim yang membedakan teater dari seni pertunjukan lainnya, yaknisastra dan seni pada umumnya(Sutiyono, 2019: 172). .

Teater modern secara luas didefinisikan sebagai pertunjukan drama atau teater musikal. Ada hubungan antara teater dan bentuk-bentuk seni balet, opera (yang menggunakan panggung, pertunjukan berkostum dengan menyanyi dan iringan orkestra) dan juga berbagai bentuk teater lainnya. Selain itu, bahwa sebagian besar ibukota negara bagian di Ethiopia tidak memiliki lembaga seni teater. Pembangunan seni teater di Ethiopia mengalami kemunduran serius, dan indikator bagaimana pentingnya sektor ini untuk pembangunan diabaikan

Departemen Seni Teater Universitas Addis Ababa dibuka pada tahun 1978, dan telah menghasilkan tenaga terampil yang diperlukan. Ini merupakan kontribusi yang sangat besar bagi perkembangan seni teater. Lulusan Departemen seni teater telah dipekerjakan oleh berbagai organisasi pemerintah dan nonpemerintah baik di tingkat federal dan regional (Sutiyono, 2017: 5). Namun, Departemen seni tetaer dengan anggaran yang sangat terbatas tidak dapat memiliki bahan penting dan peralatan teknis seperti pencahayaan dan sistem suara, komputer, printer, pemindai, dan sebagainya. Fakta bahwa auditorium Departemen seni teater di Amist Kilo, sebuah kota kecil di Ethiopia berfungsi sebagai pusat konferensi telah mempengaruhi proses belajar mengajar seni teater di Ethiopia.

Ethiopia telah memulai praktik seni teater dalam sistem pendidikan dengan kurikulum yang terstruktur selama ketika didirikan universitas pertama di Ethiopia yaitu Universitas Addis Ababa yang terletak di ibukota Ethiopia. Dalam proses ini, Ethiopia memiliki periode praktis akademik yang panjang. Pada bagian selanjutnya akan dibahas tentang aspek-aspek kurikulum.Kata "kurikulum" seperti yang didefinisikan dari asal-usul bahasa Latin awalnya berarti secara harfiah "untuk menjalankan proses pengajaran. Jika seseorang berpikir tentang maraton dengan penanda mil, penunjuk arah, stasiun air, dan pejabat serta pelatih di sepanjang rute, definisi awal ini adalah metafora untuk apa kurikulum telah menjadi dalam pendidikan anak-anak kita. Berikut adalah beberapa definisi kurikulum, dari Oliva (1997:4), bahwa kurikulum adalah apa yang diajarkan di sekolah, satu set subjek, konten, program studi, satu set bahan, urutan kursus, satu set tujuan kinerja, kursus studi, segala sesuatu yang terjadi di dalam sekolah, termasuk kegiatan di luar kelas, bimbingan, dan hubungan interpersonal, segala sesuatu yang direncanakan oleh personil sekolah, seangkaian pengalaman yang dialami oleh peserta didik di sekolah, dan apa yang dialami oleh seorang pelajar selama ia berperan sebagai pelajar dalam program seni teaer di sekolah.

Definisi dari Wilson (1990) tentang kurikulum adalah apa saja dan segala sesuatu yang mengajarkan pelajaran, terencana atau tidak. Manusia dilahirkan untuk belajar; dengan demikian, kurikulum yang dipelajari sebenarnya mencakup kombinasi dari semua yang berikut, yang tersembunyi, nol, tertulis, politik dan sosial, dan lain-lainnya. Oleh karena siswa belajar sepanjang waktu melalui paparan dan perilaku yang ditiru, ini berarti bahwa mereka belajar pelajaran sosial dan emosional yang penting dari semua orang yang menghuni sebuah sekolah, dari staf kebersihan, sekretaris, pekerja kafetaria, teman sebaya mereka, serta dari deportemen, perilaku dan sikap yang diungkapkan dan dimodelkan oleh 
guru mereka. Banyak pendidik tidak menyadari pelajaran teateryang diberikan kepada remaja melalui kontak sehari-hari ini membuat pelajar tidak mampu menguasai semuanya.

Kurikulum adalah elemen paling penting untuk merumuskan pengalaman pendidikan. Diasumsikan bahwa ada peluang yang sama bagi siswa yang menerima pengalaman pendidikan di kelas tertentu. Dalam hal ini perolehan pendidikan dapat diprediksi dan semua siswa kemungkinan memiliki akses ke peluang yang adil. Pengetahuan kurikulum yang mengarah pada pengaturan pengalaman siswa dalam pendidikan formal adalah masalah penting dalam kurikulum yang dimaksudkan dan diusulkan dalam aliran pemikiran yang sama.

Masalah penelitian adalah bidang yang menjadi perhatian, yaitu kondisi yang harus diperbaiki, kesulitan untuk dihilangkan, atau pertanyaan yang mengganggu dalam literatur ilmiah. Dalam teori dan praktik yang ada poinpoin tersebut menunjukkan kebutuhan untuk pemahaman yang bermakna dan investigasi yang disengaja. Masalah penelitian tidak menyatakan bagaimana melakukan sesuatu, menawarkan proposisi yang kabur atau luas, atau menyajikan pertanyaan nilai. Industri teater sangat penting untuk menunjukkan citra negara dalam pergaulan bangsa di seluruh dunia. Untuk memiliki industri teater standar, harus ada dukungan dari para profesor. Para profesor menyiapkan kurikulum yang dibayangkan melalui berbagai perspektif. Apa yang dibayangkan oleh masyarakat sebagai pembelajaran yang penting merupakan kurikulum yang dimaksudkan.

Karena biasanya disajikan dalam dokumen resmi, itu mungkin juga disebut kurikulum "tertulis" atau "resmi". Namun, di tingkat kelas, kurikulum yang dimaksudkan ini mungkin diubah melalui serangkaian interaksi kelas yang kompleks, dan apa yang sebenarnya disampaikan dapat dianggap sebagai kurikulum "yang diimplementasikan". Apa yang benarbenar dipelajari peserta didik (yaitu apa yang dapat dinilai dan dapat ditunjukkan sebagai hasil pembelajaran/kompetensi pembelajar) merupakan "tercapai" atau kurikulum "yang dipelajari". Selain itu, teori kurikulum menunjuk ke kurikulum "tersembunyi" (yaitu pengembangan nilai-nilai pribadi dan kepercayaan yang tidak disengaja dari peserta didik, guru dan masyarakat; dampak tak terduga dari suatu kurikulum; aspek-aspek yang tidak terduga dari proses pembelajaran).

Mereka yang mengembangkan kurikulum yang dimaksud harus memiliki semua dimensi kurikulum yang berbeda ini dalam pandangan dan mereka harus terhubung dengan industri tempat siswa bekerja setelah granulasi mereka. Meskipun kurikulum "tertulis" tidak menguras makna kurikulum, kurikulum itu penting karena mewakili visi masyarakat dan latar budaya negara tertentu. Kurikulum tertulis karenanya harus dinyatakan dalam dokumen yang komprehensif dan ramah pengguna, seperti kerangka kerja kurikulum; kurikulum mata pelajaran, dan dalam materi pembelajaran yang relevan dan bermanfaat, seperti buku teks; panduan guru; penilaian memandu industri seni teater. Tetapi ketika kita melihat industri teater di Ethiopia, itu tidak berhubungan dengan output kurikulum, masih sarjana universitas menyalahkan industri teater vs. industri teater juga menyalahkan universitas. Ini menuduh satu sama lain pengungkapan menghasilkan siswa miskin akademik yang menyebabkan industri teater dirampas.

Berdasarkan pengamatan pribadi saya yang utama, industri teater di Ethiopia tidak sangat terkait dengan kurikulum universitas. Jadi, penelitian ini tertarik untuk menganalisis analisis seni teater Ethiopia; studi kasus program sarjana melalui praktik dalam seni kreatif.

Penelitian ini dibatasi fokus / masalah yang ditargetkan investigasi seni teater Ethiopia; studi kasus program sarjana melalui praktik dalam seni akal. Sesuai dengan tujuan proposal penelitian ini, akan menilai praktik terbaik seni teater di program sarjana Ethiopia. Selain itu, area fokus penelitian ini terbatas hanya di Addis Ababa University (AAU), Ethiopia bahwa kurikulum modul sarjana seni teater yang diselaraskan di tingkat nasional. 


\section{METODE}

Berdasarkan faktor-faktor seperti orientasi ideologis umum yang mendasari dalam penelitian ini, metode pengumpulan data akan digunakan, sifat data yang dikumpulkan, dan metode analisis data untuk memperoleh hasil penelitian pada dasarnya dianggap metode kualitatif. Dalam edisi kedua Buku Pegangan Penelitian Kualitatif oleh, Denzin dan Lincoln menawarkan definisi berikut. Penelitian kualitatif adalah aktivitas yang menempatkan pengamat di dunia untuk menempatkan serangkaian interpretatif dan praktik material yang membuat dunia terlihat. Praktik-praktik ini mengubah dunia menjadi serangkaian representasi termasuk catatan lapangan, wawancara, percakapan, foto, rekaman dan memo menjadi diri sendiri. Pada tingkat ini, penelitian kualitatif melibatkan pendekatan interpretif, naturalistik terhadap dunia. Ini berarti bahwa peneliti kualitatif mempelajari hal-hal dalam pengaturan alaminya, berusaha memahami, atau menafsirkan, fenomena dalam arti makna yang dibawa orang (Denzin dan Lincoln, 2000: 3). Berdasarkan fakta ini, subjek dipilih secara acak dan sengaja. Ini berarti bahwa peneliti akan dipilih secara sengaja dan dua dokumen akan diambil secara acak.

Subjek analisis adalah dokumen kurikulum pendidikan seni teater Ethiopia. Oleh karena itu, peneliti akan menggunakan metode pengambilan sampel acak sederhana untuk mengumpulkan data dari dokumen kurikulum seni teater program sarjana Ethiopia dan Indonesia. Studi ini akan berfokus pada 'analisis seni teater Ethiopia; dalam seni teater terapan praktis terkait dalam kreativitas program sarjana. Jadi, data pencarian akan dikumpulkan di Ethiopia, selama waktu berdasarkan tabel waktu dari proposal ini. Penelitiannya dari waktu mulai sampai penelitian yang dipublikasi disajikan akan memakan waktu sekitar 8-12 bulan (tentatif). Penelitian ini adalah penelitian deskriptif dokumen analitik. Di Ethiopia terdapat sekolah seni pemerintah dan nonpemerintah yang berbeda. Tetapi memasukkan semua potensi kurikulum universitas seni tidak mungkin untuk dikelola. Sehingga peneliti akan menggunakan metode pengambilan sampel acak sederhana untuk mengumpulkan data dari Ethiopia data yang diperlukan untuk studi analisis seni teater Ethiopia; studi kasus program sarjana melalui praktik dalam seni kreatif. Menurut yang disebutkan di atas penelitian ini akan membutuhkan seni teater Ethiopia dalam program sarjana yang saat ini aktif. Ada tiga jenis metodologi pengumpulan data dalam penelitian. Itu dikenal sebagai wawancara, observasi, studi dokumen dan peneliti telah berencana untuk menganalisis aspek perbandingan kurikulum seni teater Ethiopia dan program pasca sarjana di Indonesia. Metode pengumpulan data studi dokumen adalah yang paling relevan dan penting. Oleh karena itu, data primer dari penelitian ini akan dikumpulkan dari dokumen kurikulum seni teater yang dipilih dari Ethiopia dan Indonesia.

Penelitian ini adalah penelitian kualitatif, atau juga jenis penelitian lain yang telah menghasilkan data non-numerik. Ini berfokus pada pengumpulan data terutama verbal daripada pengukuran. Informasi yang terkumpul kemudian dianalisis dengan cara interpretatif, subyektif, impresionistik atau bahkan diagnostik. Penelitian ini bertujuan untuk mengeksplorasi kurikulum pendidikan seni teater melalui aspek-aspek terapan kreatif dan wawasan yang relevan. Untuk mempelajari kurikulum seni teater pendidikan tingkat program sarjana Ethiopia aspek kapasitas praktis lulusan baru, peneliti berpikir bahwa metode penelitian kualitatif akan menjadi yang paling tepat. Dalam makalah ini, peneliti akan mengeksplorasi secara singkat kemungkinan dan wawasan yang relevan tentang kurikulum seni teater di Ethiopia melalui seni kreatif dalam program sarjana berdasarkan aspek analisis deskriptif yang ditemukan dalam kurikulum seni teater di Ethiopia.

\section{HASIL DAN PEMBAHASAN}

Kurikulum Pendidikan adalah segala sesuatu yang mengajarkan pelajaran secara terencana. Manusia dilahirkan untuk belajar. Dengan demikian, kurikulum yang dipelajari 
sebenarnya mencakup kombinasi dari semua hal berikut baikyang tersembunyi maupun yang tertulis. Karena siswa belajar sepanjang waktu melalui pemaparan dan perilaku model, ini berarti bahwa mereka belajar pelajaran sosial dan emosional. Yang penting, dari semua orang yang belajar di sebuah sekolah, termasuk staf kebersihan, sekretaris, pekerja kafetaria, rekanrekan mereka, serta dari deportasi, perilaku dan sikap yang diungkapkan dan dimodelkan oleh guru-guru mereka. Banyak pendidik tidak menyadari pelajaran kuat yang diberikan kepada remaja (Wilson, 1990). Kurikulum dapat dibayangkan dari berbagai perspektif. Apa yang dibayangkan oleh masyarakat sebagai pengajaran dan pembelajaran yang penting merupakan kurikulum yang dimaksudkan. Karena biasanya disajikan dalam dokumen resmi, itu mungkin juga disebut kurikulum "tertulis" atau "resmi". Namun, di tingkat kelas, kurikulum yang dimaksudkan ini mungkin diubah melalui serangkaian interaksi kelas yang kompleks, dan apa yang sebenarnya disampaikan dandapat dianggap sebagai kurikulum yang diimplementasikan.

Apa yang benar-benar dipelajari peserta didikyaitu apa yang dapat dinilai dan dapat ditunjukkan sebagai hasil pembelajaran/ kompetensi pembelajar merupakan capaian atau kurikulum "yang dipelajari. Selain itu, teori kurikulum menunjuk ke kurikulum "tersembunyi" yaitu pengembangan nilai-nilai pribadi dan kepercayaan yang tidak disengaja dari peserta didik, guru dan masyarakat; dampak yang tidak terduga dari suatu kurikulum; aspek-aspek yang tidak terduga dari proses pembelajaran). yang mengembangkan kurikulum yang dimaksud harus memiliki semua dimensi kurikulum yang berbeda ini dalam pandangan. Sementara kurikulum "tertulis" tidak melelahkan saya Dalam kurikulum, ini penting karena mewakili visi masyarakat. Kurikulum "tertulis" karenanya harus diungkapkan dalam dokumen yang komprehensif dan ramah pengguna, seperti kerangka kerja kurikulum; kurikulum/silabus mata pelajaran, dan dalam materi pembelajaran yang relevan dan bermanfaat, seperti buku teks; panduan guru; panduan penilaian.

Dalam beberapa kasus, orang melihat kurikulum sepenuhnya dalam hal mata pelajaran yang diajarkan, dan sebagaimana diatur dalam set buku teks, dan melupakan tujuan yang lebih luas dari kompetensi dan pengembangan pribadi. Inilah sebabnya mengapa kerangka kerja kurikulum penting. Ini menetapkan subjek dalam konteks yang lebih luas ini, dan menunjukkan bagaimana pengalaman belajar dalam subjek perlu berkontribusi untuk pencapaian tujuan yang lebih luas. Semua dokumen ini dan masalah yang mereka rujuk membentuk "sistem kurikulum". Diberi fungsi membimbing mereka untuk agen pendidikandan para pemangku kepentingan, dokumen dan bahan kurikulum yang jelas, terinspirasi dan memotivasi memainkan peran penting dalam memastikan kualitas pendidikan. Keterlibatan pemangku kepentingan (termasuk dan terutama guru), dalam pengembangan kurikulum tertulis adalah sangat penting untuk memastikan kepemilikan dan keberlanjutan proses kurikulum.

Kurikulum adalah elemen paling penting untuk merumuskan pengalaman pendidikan. Diasumsikan bahwa ada peluangyang samabagi siswa yang menerima pengalaman pendidikan di kelas tertentu. Dalam hal ini perolehan pendidikan dapat diprediksi dan semua siswa kemungkinan memiliki akses ke peluang yang adil. Pengetahuan bagaimana kurikulum mengarah pada pengaturan pengalaman siswa secara formal. Pendidikan adalah masalah penting dalam kurikulum kurikulum yang dimaksudkan dan diusulkan dalam aliran pemikiran yang sama. Menurut pandangan pakar pendidikan yang berbeda ada berbagai jenis kurikulum. Berikut ini mewakili berbagai jenis kurikulum yang digunakan di sekolah saat ini. Jelas, kurikulum tertulis, kurikulum sosial, kurikulum sosial (kurikulum sosial), kurikulum hantu, kurikulum nol, kurikulum bersama, kurikulum retoris, kurikulum yang digunakan, kurikulum yang diterima, kurikulum internal, dan kurikulum elektronik. 
Mari kita simak deskripsi singkat berikut ini. Sebuah kurikulum terbuka, eksplisit, atau tertulis. Inihanya apayang ditulis sebagai bagian dari instruksi formal pengalaman di sekolah, dapat merujuk pada dokumen kurikulum, teks, film, dan bahan pengajaran yang mendukung secara terbuka dipilih untuk mendukung agenda pengajaran yang disengaja dari suatu sekolah. Dengan demikian, kurikulum terbuka biasanya terbatas pada pemahaman dan arahan tertulis yang secara formal ditunjuk dan ditinjau oleh administrator, direktur kurikulum dan guru. Dokumen itu muncul di propinsi-propinsi atau di negara bagian sebagi pedoman kurikulum daerah. Hal tersebut banyak dipergunakan sebagai dokumen perencanaan guru yang diberikan di sekolah.

Demikian pula kurikulum tersembunyi mengacu pada pelajaran, nilai, dan perspektif yang tidak tertulis, tidak resmi, dan sering tidak disengaja dipelajari siswa di sekolah. Rasanya seperti kurikulum "formal" terdiri atas kursus, pelajaran, dan kegiatan belajar siswa berpartisipasi dalam, serta pengetahuan dan keterampilan yang secara sengaja diajarkan oleh para pendidik kepada siswa. Kurikulum tersembunyi terdiri dari pesan akademik, sosial, dan budaya yang tak terucapkan atau tersirat yang disampaikan kepada siswa saat mereka berada di sekolah. Ini adalah kurikulum yang tidak disengaja yang tidak direncanakan tetapi dapat memodifikasi perilaku atau mempengaruhi hasil belajar yang terjadi di sekolah kurikulum tersembunyi dimulai sejak awal pendidikan anak. Siswa belajar membentuk opini dan ide tentang lingkungan mereka dan teman sekelas mereka. Misalnya, anak-anak belajar cara-cara yang 'pantas' untuk bertindak di sekolah, artinya apa yang akan membuat mereka populer di kalangan guru dan siswa.

Mereka juga belajar apa yang diharapkan dari masyarakat yaitu memahami fakta bahwa nilai ujian akhir tahun adalah yang paling penting. Kurikulum itu diajarkan, sehingga memberi siswa pesan bahwa unsur-unsur ini tidak penting dalam pengalaman pendidikan mereka atau dalam masyarakat kita. Eisner menawarkan beberapa poin utama saat ia menyimpulkan pembahasannya tentang kurikulum nol. Poin utama yang saya coba sampaikan sejauh ini adalah bahwa sekolah memiliki konsekuensi tidak hanya berdasarkan apayangmerekaajarkan, tetapijugaberdasarkan apa yang mereka lalai untuk diajarkan. Apa yang tidak dapat dipertimbangkan oleh siswa, proses yang tidak dapat mereka gunakan, memiliki konsekuensi untuk jenis kehidupan yang mereka jalani. Dari perspektif Eisner, kurikulum noladalah kurikulum sederhana yang tidak diajarkan di sekolah. Entah bagaimana, di suatu tempat, beberapa orang diberdayakan untuk membuat keputusan sadar tentang apa yang akan dimasukkan dan apa yang harus dikeluarkan dari kurikulum. Karena secara fisik tidak mungkin untuk mengajarkan segala sesuatu di sekolah, banyak topik dan mata pelajaran harus dengan sengaja dikeluarkan dari kurikulum tertulis.

Jika disertakan pendekatan perilaku menjadi pendekatan referensi untuk kurikulum. Behaviorisme initerutama berkaitan dengan aspek perilaku manusia yang dapat diamati dan diukur (Standridge, 2002: 1). Menurut Power (1982: 168), prinsip dasar behaviorisme adalah apa pun yang dapat diketahui tentang manusia harus berasal dari pengamatan perilaku. Apalagi, harus dilakukan sesuai dengan metode ketat prosedur ilmiah yang digunakan dalam ilmu fisika. Jadi, pendekatan perilaku menjadi preskriptif dan didasarkan pada prinsip-prinsip teknis dan ilmiah. Ini terdiri dari paradigma strategi bertahap dan rinci untuk merumuskan kurikulum. Pendekatan ini umumnya didukung oleh rencana yang menetapkan tujuan dan sasaran. Isi dan kegiatan yang disusun, terstruktur, metodologis, dan hasil pembelajaran dengan kriteria dan formulir evaluasi yang sesuai, dengan mempertimbangkan tujuan dan sasaran kurikulum yang ditetapkan. Dengan demikian, pendekatan perilaku mencakup pengembangan kurikulum dalam arti yang lebih luas. Ini tidak terbatas pada evaluasi kurikulum. Hasil belajar ini adalah keterampilan, pengetahuan dan perilakuyang terkandung dalam kurikulum 
nasional dan merupakan dasar dari semua ujian dan tes eksternal serta laporan pembelajaran siswa. Selain itu, hasil pembelajaran adalah persyaratan mendasar atau tolok ukur yang ditunjuk untuk meminta pertanggungjawaban sekolah dan guru dalam hal ini menghasilkan bukti yang dapat diverifikasi tentang kecukupan prestasi peserta didik (Lovat \& Smith 2003).

Di samping pendekatan perilaku, juga terdapat pendekatan manajerial. Pendekatan manajerial memerlukan pertimbangan sekolah sebagai sistem sosial, berdasarkan pada teori organisasi, di mana anggota konstituen (misalnya siswa, guru, kurikulum, dan administrator) berinteraksi secara harmonis dengan norma dan perilaku tertentu. Dalam konteks ini pendekatan manajerial berfokus pada program, jadwal, ruang, sumber daya dan peralatan, serta personel, yang membutuhkan kerja sama antara guru, siswa dan mereka yang bertanggung jawab untuk pengawasan kurikulum di luar sekolah. Ornstein \& Hunkins (1993: 3) mencatat bahwa "pertimbangan diberikan kepada komite dan proses kelompok, hubungan manusia, gaya dan metode kepemimpinan, dan pengambilan keputusan. Dengan kata lain, pendekatan manajerial lebih menekankan pada aspek pengawasan dan administrasi kurikulum, dengan fokus utama pada aspek organisasi dan aspek proses implementasi. Pendekatan manajerial berkaitan dengan perubahan dan inovasi, mengeksplorasi "bagaimana spesialis kurikulum, pengawas, dan administrator dapat memfasilitasi proses ini" (Ornstein \& Hunkins, 1993: 3).

Di bawah sudut pandang ini, spesialis atau supervisor kurikulum dianggap sebagai fasilitator, narasumber (orang yang tersedia untuk membantu guru atau kolega untuk mencapai tujuan kurikulum). Seperti disebutkan sebelumnya, strategi implementasi yang digunakan untuk memperkenalkan kurikulum pendidikan dasar baru sebagaimana didefinisikan dalam pendekatan manajerial. Memang, pendekatan manajerial menegaskan bahwa keberhasilan setiap inisiatif perubahan kurikulum tidak diragukan, tergantung pada penggunaan yang tepat dari strategi implementasi, yang membaca pendekatan manajerial disesuaikan disesuaikan diterjemahkan ke dalam strategi implementasi yang efektif (lihat bagian 3.4 dari laporan ini). Yang terpenting, pengamatan berikut oleh Hall and Hord (2001: 13-14) menjadi prinsip panduan sejak awal. Administrator juga harus mengamankan perubahan infrastruktur yang diperlukan dan dukungan sumber daya jangka panjang jika menggunakan (Ayuningtyas, 2018: 139).

Di antara nama-nama lain, pendekatan sistem untuk merancang kurikulum juga disebut desain sistem pembelajaran. Sesuai dengan Clark (1989: 3), pendekatan sistem atau desain pembelajaran dapat dipahami sebagai model sistematis yang digunakan untuk merencanakan, merancang, mengembangkan, dan mengevaluasi pelatihan, yang mencakup komponen-komponen berikut: (1) analisis kebutuhan; (2) analisis tugas; (3) definisi tujuan pembelajaran; (4) pengembangan rencana penilaian; (5) pengembangan materi pembelajaran; (6) rencana untuk mencoba dengan revisi (uji coba) dan (7) implementasi produk akhir.

Definisi Clark (1989) tentang pendekatan sistem mengklasifikasikannya berdasarkan pendekatan perilaku karena dirancang untuk mencapai tujuan atau tujuan yang jelas dan terukur. Ornstein \& Hankins (1993) menyatakan bahwa fitur utama dari pendekatan sistem adalah keterkaitan berbagai program dan area konten yang termasuk dalam kurikulum.

\section{KESIMPULAN}

Kurikulum secara bersamaan memuat tentang apa yang diajarkan di sekolah, danapa yangakan disiapkandirumah, sertapengalamanpengalaman yang merupakan bagian dari pengalaman keluarga, atau pengalaman di luar lingkungan keluarga dan lingkungan sosial. terkait yang disetujui oleh keluarga. Demikian juga kurikulum yang diterima di gereja, dalam konteks ekspresi keagamaan, pelajaran tentang nilai-nilai, etika atau moral, perilaku yang dibentuk, atau pengalaman sosial. Di samping itu, kurikulum retoris berasal dari para 
profesional yang terlibat dalam pembentukan konsep dan perubahan konten pendidikan seni teater; dari inisiatif pendidikan yang dihasilkan dari keputusan berdasarkan laporan nasional dan negara, pidato publik, dari teks-teks yang mengkritik praktik pendidikan yang ketinggalan zaman. Kurikulum retoris juga dapat berasal dari karya-karya yang dipublikasikan yang menawarkan pembaruan dalam pengetahuan pedagogis.

Digunakan; Kurikulum formal (tertulis atau terbuka) terdiri dari hal-hal itu dalam buku pelajaran, dan konten serta konsep dalam panduan kurikulum daerah. Namun, unsurunsur "formal" itu sering tidak diajarkan. Kurikulum yang digunakan adalah kurikulum aktual yang disampaikan dan disajikan oleh setiap guru. Kurikulum yang diterimameliputi hal-hal yang siswa ambil dari ruang kelas; konsep dan konten yang benar-benar dipelajari dan diingat.

Kurikulum internal; proses, konten, pengetahuan dikombinasikan dengan pengalaman dan realitas pembelajar untuk menciptakan pengetahuan baru. Sementara pendidik harus menyadari kurikulum ini, mereka memiliki sedikit kendali atas kurikulum internal karena ini unik untuk setiap siswa. Kurikulum elektronik; pelajaran-pelajaran tersebut dipelajari melalui pencarian informasi di Internet, atau melalui penggunaan e-bentuk komunikasi.

\section{DAFTAR PUSTAKA}

Addis Ababa University. (2014). Modular curriculum for undergraduate program, school of theatre arts, In Ethiopia. Un published.

Allan A. Glatthorn, Floyd Boschee, Bruce M. Whitehead (2009) Curriculum Leadership, Fourth Edition The University of South Dakota Bruce M. Whitehead University of Montana, USA,

Aronyeshitila. (2010). Ethiopian Theatre at a Glimpse. https://arefe.wordpress. com/2010/05/06/ethiopian-theatre-at-aglimpse/
Ayuningtyas, DP., Sutiyono, S. 2018. Eksistensi Kesenian Barongan Setyo Budoyo di Desa Loram Wetan Kecamatan Jati Kabupaten Kudus. Imaji: Jurnal Seni dan Pendidikan Seni, 2, 138-146.

Bilbao, P. P., Lucido, P. I., Iringan, T. C., and Javier, R. B. (2008).Curriculum development. Philippines: Lorimar Publishing, Inc.

Bobbitt, F. (1918). The curriculum: a summary of the development concerning the theory of curriculum.

Bobbitt, Franklin. (1924). How to Make a Curriculum. Boston: Houghton Mifflin.

Cortes, C.E. (1981). The societal curriculum: Implications for multi-ethnic educations. In Banks, J.A (ed.) Educations in the 80's: Multi-ethnic education. National Education Association.

Eisner, E.W. (1994). the educational imagination: On design and evaluation of school programs. (3rd. ed) New York: Macmillan.

Hodgort Matthew. (1969). Satire. London: world university library.

Longstreet, W.S. and Shane, H.G. (1993). Curriculum for a new millennium. Boston: Allyn and Bacon.

Lincoln, Y.S. and Guba, G.E. (1985). Naturalistic Inquiry, Beverley Hills, CA: Sage

Oliva, P. (1997). The curriculum: Theoretical dimensions. New York: Longman.

Ornstein, A., \& Hunkins, F. (2009). Curriculum Design. In Curriculum: Foundations, Principles and Issues (5th Ed.), pp. 181206. Boston, MA: Pearson/Allyn and Bacon.

Slavin, R., Madden, N., Calderon, M., Chamberlain, A., \& Hennessy, M. (2011). Reading and language outcomes of a multiyear randomized evaluation of transitional bilingual education. Educational evaluation and policy analysis. 33 (1): 47-58.

Sutiyono, S. (2017). Art Atraction As the Media of Learning to Have a Meaningfull 
Learning. Asian Journal of Management Science \& Education, 6(3), 1-8.

Sutiyono, S. (2019). An art Phenomenon Under the State Controll: Case Study on Shadow Puppet Performance. Asian Social Science, 15(2), 172-176.

Tyler, RW.(1971). Basic principle of curriculum and instruction. Chicago: The University of Chicago Press.

Wilson, L. O. (1990, 2004, 2006) Curriculum course packets ED 721 \& 726, unpublished.
Wheel, D.K. (1978). Curriculum process. London: hodder and Stoughton.

West Bank and Gaza 2011. (2006). Emergency service support project (ESSP) MDTF and ESSP III 2006 - 2011. The World Bank Group Integrity vice Presidency Publisher. Yonas Adamu Chernet. (2014). Political Satire in Abebe Tola's "Yabe Tokichaw Shimutochi" and "Yabe Tokichaw Mitsetochi" Essays. International Journal of Literature and Arts.Vol. 2, no.6, 